\title{
Inbaltåนี
}

Borte

Bortoort . . . . . . . . . . . . . . . . . . III

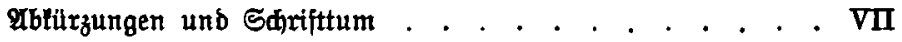

Einleitung. . . . . . . . . . . . . . . . . . 1

Getwerbjteuergejes vom 9 . Suli 1926 nach bem Bortlaut ber $\mathfrak{B e}=$ tanntmađung bom 10 . Iugujt 1926 . . . . . . . . . 16

\section{Anfang :}

Inlagen zur Befanntmađung zum Bollzuge bes Serverbjteuer= gejebes vom 27. Aluguit 1926 . . . . . . . . . . . 216

Befes vom 9. Juli 1926 zur 代berung bes Bemerb|teuergejebes bom 27 . Juli 1921 in ber Faffung bez హejełes vom 18. Juli 1923242

Safjregifter . . . . . . . . . . . . . 248 